
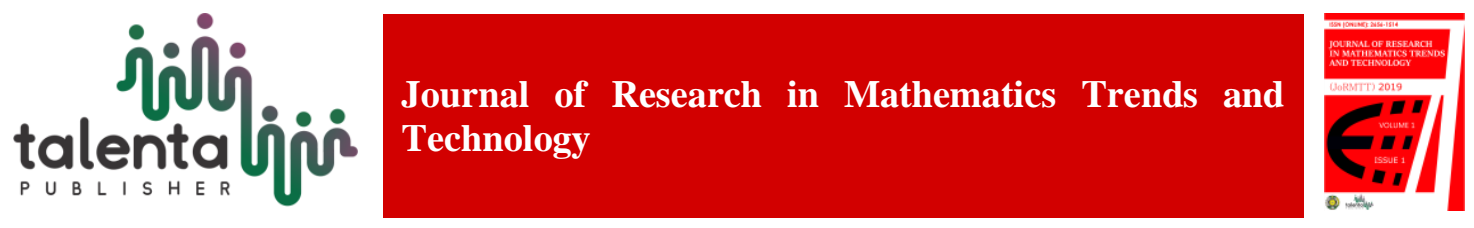

\title{
Using The Problem Posing Learning Model Based on Open Ended to Improve Mathematical Critical Thinking Ability
}

\author{
Andy Sapta ${ }^{1 *}$, Sondang Purnama Pakpahan ${ }^{2}$ and Syahriani Sirait ${ }^{3}$ \\ ${ }^{1}$ Sekolah Tinggi Manajemen Informatika dan Komputer Royal, Kisaran, Indonesia \\ ${ }^{2}$ Open University, Indonesia \\ ${ }^{3}$ Asahan University, Indonesia
}

\begin{abstract}
The problem of this study is the low student mathematics learning outcomes caused by the lack of critical ability. The purpose of this study is to use the problem posing learning model based on open ended to improve mathematical critical thinking abilities. The population is the second semester of Asahan University students, amounting to 110 people. The sample is obtained using the cluster random sampling method. The study sample was two classes from 3 classes. The implementation of this research by giving use the problem posing learning model based on open ended. Data collection techniques by giving tests to students who are sampled. The research data shows that by applying the use of the problem posing learning model based on open ended to improve athematic critical thinking abilities in participating in probability courses.
\end{abstract}

Keywords: Problem Posing, Open Ended, Probability

\begin{abstract}
Abstrak. Masalah dari penelitian ini adalah rendahnya hasil belajar siswa dalam pelajaran matematika yang disebabkan oleh kurangnya kemampuan berpikir kritis. Tujuan dari penelitian ini adalah untuk menggunakan model pembelajaran problem posing berbasis open ended untuk meningkatkan kemampuan berpikir kritis secara matematis. Populasi penelitian ini adalah mahasiswa semester 2 Universitas Asahan yang berjumlah 110 orang. Sampel diperoleh dengan menggunakan metode cluster random sampling. Sampel penelitian adalah dua kelas dari tiga kelas. Implementasi penelitian ini dengan menggunakan model pembelajaran problem posing berbasis open ended. Data dikumpulkan dengan memberikan tes kepada siswa yang merupakan sampel. Data penelitian ini menunjukkan bahwa dengan menerapkan penggunaan model pembelajaran problem posing berbasis open ended untuk meningkatkan kemampuan berpikir kritis dalam berpartisipasi di kursus probabilitas.
\end{abstract}

Kata Kunci: Problem Posing, Open Ended, Probabilitas

Received 16 November 2018 | Revised 18 January 2019| Accepted 25 February 2019

\section{Introduction}

Mathematics is a subject that trains students to think critically, creatively, express their thoughts in both oral and written systematically, logically and straightforwardly [1]. Therefore mathematics is one of the main subjects in schools both in elementary schools and universities.

*Corresponding author at: Sekolah Tinggi Manajemen Informatika dan Komputer Royal, Kisaran, Indonesia

E-mail address: sapta@royal.ac.id 
This is because mathematics is a fundamental mastery that can foster students' reasoning abilities and means to solve problems in everyday life. [2] In solving problems, a person needs critical thinking skills. Problem solving is an attempt to overcome obstacles when the answer is not yet clear.

The reality is that students think less critical, students also get bored easily. The causes of students' critical thinking are low, among others: students do not master the understanding of study material in the field of study. In the classroom lecturers often use a lecturer-centered approach so students feel bored and less attractive for learning and no feedback occurs. To develop critical thinking students need a model that can develop student activity in the learning process.

[3] Some indicators of creative thinking skills are: (1) Answering questions more than one answer (fluency), (2) Answering questions in various (flexible) ways, (3) Give another answer than usual (Original), (4) Develop ideas or ideas for answers to a problem (elaboration).

Problem posing is the activity of formulating new questions from modification of the condition of the problem so that it is able to complete its own solution [4]. The relationship between problem posing and critical thinking of students is that students who use problem posing learning models can significantly improve their mathematical critical thinking skills. The problem posing learning model strongly supports the implementation of the principle of learning through stages including: making mathematical situations, mathematical questions, solving math problems, and applying mathematics.

Therefore the choice of learning approach becomes very important and must be adapted to students' thinking abilities, because this math subject requires the ability to think, communicate, accuracy, accuracy of the calculations in its completion. One of the learning programs that can be done is learning based problem posing model.

Giving open-ended problems can improve students' critical thinking skills. [4] Open-ended problems have aspects of openness, namely: (1) open end results because they have many correct answers, (2) the solution process is open because it has many approaches to getting the right answers, and (3) open development because it is possible the submission of new problems by changing some conditions in the previous problem. The open-ended problem referred to in this study is a mathematical problem that requires students to provide many ways of solving. The aspect of openness in open-ended math questions is included in the classification of the type of problem that is open to the completion process, where the problem has a variety of solutions.

\section{Materials and Methods}

This type of research is quasi experiment. The group used in this study consisted of two groups. One group as a control group uses conventional learning methods that are teacher center, and one group as an experimental group by using of learning based problem posing model.

This research was conducted at Asahan University, North Sumatera, Indonesia. The population of this study is the student of the study program of mathematics education in the even semester of 2017/2018. The study population is 110 students divided into 3 classes. The sample of this 
research is obtained by using cluster random sampling technique. The study sample consisted of two classes, one class for the experimental group and one class for the control group.

The data of this study are quantitative data in the form of student mathematics learning outcomes data that are influenced by the ability of critical thinking in mathematics in probability subjects. The research data is in the form of student learning outcomes at the beginning of learning (before an experiment is conducted) and at the end of learning (after being given treatment).

\section{Results and Discussion}

The average value and standard deviation of critical thinking skills in mathematics with use of learning based problem posing models for increasing mathematical critical thinking ability in probability subjects is shown in Table 1 and Table 2.

Table 1 Dimensions of descriptive statistics before learning carried out experiments

\begin{tabular}{llll}
\hline & $\mathrm{N}$ & Mean & SD \\
\hline Experiment Class & 35 & 68.91 & 2.73 \\
Control Class & 35 & 69.52 & 2.95 \\
\hline
\end{tabular}

Table 2 Dimensions of descriptive statistics after learning carried out experiments

\begin{tabular}{llll}
\hline & $\mathrm{N}$ & Mean & SD \\
\hline Experiment Class & 35 & 76.31 & 1.38 \\
Control Class & 35 & 70.62 & 2.87 \\
\hline
\end{tabular}

The data in Table 1 found that before the treatment there were no significant differences from the two sample groups. Both sample groups have values that are not statistically different for the effectiveness of lecturers in teaching, provide motivation in learning, direct students more actively and creatively in the learning process, and effective teaching.

After treatment of the experimental class and the control class, the two sample classes increased student learning outcomes. These learning outcomes are certainly influenced by the ability to think critically in solving questions given to them when the learning process occurs. In the experimental class the treatment was given in the form of using learning based problem posing models. In the control class the lecturer only provides motivation in solving the questions given.

To determine whether the learning model In the experimental class the treatment of the problem of using learning based problem posing models differs significantly with the control class, the statistical test is performed by using t-test independent at a significant level of 0.05 .

Table 3 t-test by sample groups of after learning models

\begin{tabular}{ccccc}
\hline Group & $\mathrm{N}$ & $\mathrm{df}$ & $\mathrm{t}$ & $\mathrm{p}$ \\
\hline Experiment Class & 35 & 68 & 0.451 & 0.618 \\
Control Class & 35 & & \\
\hline
\end{tabular}

As is known from Table 3, the results of an independent t-test indicate that there are statistically significant differences between the averages $\left(t_{(144)}=0.451, p>0.05\right)$. It is known that the experimental class the problem of using learning based problem posing models has a higher value than the control class. 
The difference in students' critical thinking skills is due to the use of learning based problem posing models that encourage students to be more active in discussing and asking fellow students or lecturers. So that, with the use of learning based problem posing, the student analysis in understanding learning might increase. By applying the steps of the use of learning based problem posing model that has been given by the lecturer, students become a lot of conducting experiments to solve the existing problems, so that the ability to think students can develop actively and creatively.

In conducting research, it is known that the use of learning based problem posing student models is directed to be able to think broadly in solving a given problem. In addition to this, students also get help from the mindset of fellow students in the discussion process. With this discussion process, it is seen that the development of the mindset of several students is more widespread so that the opportunity to solve each problem is more wide open.

Giving more challenging and open questions to the experimental group made students more excited. This is due to the high motivation that occurs due to the unification of the mindset of some students during the discussion.

Unlike the case that occurred in the control group. Students are more monotonous in working on the questions given. Even though the lecturer has directed to be more critical in responding to each question given but cannot run optimally. This is because students are more likely to be individual in solving existing problems.

\section{Conclusion}

The use of learning based problem posing is better used in learning because it can improve students critical thinking skills in learning, especially in probability subjects. By increasing students critical thinking skills they can improve student learning outcomes.

\section{REFERENCES}

[1] A. Sapta, "Use of Edmodo In Improving Self-Efficacy", Prosiding Universitas Medan Area, vol. 1, no. 1, 2018.

[2] W. Khusnawiyati and M. E. G. A. Teguh Budiarto, "Profil Berpikir Kritis Siswa SMP Dalam Menyelesaikan Masalah Open Ended Ditinjau dari Kemempuan Matematika", MATHEdunesa, vol. 7, no. 2, 2018.

[3] Firdaus, "Meningkatkan Kemampuan Berpikir Kreatif Matematis Siswa SMA Melalui Pembelajaran Open Ended Pada Materi SPLDV", Jurnal Pendidikan Matematika, vol. 1, no. 2, pp. 227-236, 2016.

[4] R. Rustina, "Efektivitas Penggunaan Model Pembelajaran Problem Possing Terhadap Kemampuan Berpikir Kritis Mahasiswa", Penelitian Pendidikan dan Pengajaran Mahasiswa, vol. 2, pp. 41-48, 2016.

[5] N. A. Turohmah, "Peningkatan Kemampuan Berpikir Kritis Matematis Siswa Melalui Penerapan Pendekatan Open Ended”, 2014. 